\title{
Perbedaan Motorik Kasar Dan Halus Bayi Diberikan Asi Eksklusif Dan Non Eksklusif
}

\section{The Difference between the Gross Motoric and the Fine Motoric of Infants with An Exclusive And A Non-Exclusive Breast Feeding}

\author{
Hermina Desitawati ${ }^{1}$ Inge Wattimena ${ }^{2}$ Natalia L Susanti ${ }^{3}$ \\ ${ }^{1}$ Fakultas Imunologi, Sekolah Pascasarja Universitas Airlangga Surabaya \\ ${ }^{2}$ Fakultas Keperawatan, Universitas Katolik Widya Mandala Surabaya \\ ${ }^{3}$ Fakultas Kedokteran, Universitas Katolik Widya Mandala Surabaya \\ Email: hermina.desitawati@yahoo.com; inge.wattimena@gmail.co.id; \\ natalia.LS@yahoo.co.id
}

\begin{abstract}
ABSTRAK
Bayi banyak yang mengalami masalah dalam perkembangan motorik sejak usia dini. Salah satu penyebabnya adalah tidak diberikan ASI eksklusif kepada bayi. Oleh karena itu, peneliti ingin mengetahui perbedaan perkembangan motorik kasar dan motorik halus pada bayi yang diberikan ASI esklusif dan ASI non eksklusif. Penelitian ini bersifat observasional dengan desain compare. Populasi dalam penelitian bayi yang pernah mendapatkan ASI dan bayi tidak mendapatkan ASI dengan usia 6-12 bulan. Sampel sebanyak 45 orang di Posyandu Puskesmas Pacarkeling Surabaya yang diambil dengan teknik purposive sampling dengan kriteria inklusi bayi yang tidak cacat fisik. Variabel independen yaitu pemberian ASI sedangkan variabel dependen yaitu motorik kasar dan motorik halus. Pengumpulan data dilakukan dengan melakukan pengukuran perkembangan motorik kasar dan motorik halus pada bayi yang diberikan ASI eksklusif dan ASI non eksklusif menggunakan DDST dan lembar wawancara. Uji hipotesis dengan menggunakan uji staistik uji t sampel independen. Hasil uji statistik menunjukkan bahwa tidak ada perbedaan perkembangan motorik halus pada bayi yang mendapatkan ASI eksklusif dan ASI non eksklusif dan tidak ada perbedaan perkembangan motorik kasar pada bayi yang mendapatkan ASI eksklusif dan ASI non eksklusif. Pemberian ASI tidak berpengaruh pada perkembangan motorik halus maupun motorik kasar. Perkembangan motorik berkembang tergantung dari latihan dan olahraga bayi.
\end{abstract}

Kata Kunci : Bayi, ASI Eksklusif dan Non Eksklusif, Motorik Halus dan Kasar

\section{ABSTRACT}

There are a huge number of infants having problem with their motoric development since their early age. One of the possible causes is a non-exclusive breast feeding to the infants. Thus, this research aims to realize the difference between the development of the gross motoric and the fine motoric of infants with an exclusive and a non-exclusive breast feeding. This research uses an observational method with a comparison design. The population of this research includes all 6-12 month-aged infants with an exclusive and a non-exclusive breast feeding. Samples are 45 people at the Integrated Healthcare Center (Posyandu) of the Public Health Center (Puskesmas) Pacarkeling Surabaya selected through purposive sampling technique with an inclusive criteria 'no physical disability'. The independent variable is breast feeding, while the dependent variables are the gross motoric and the fine motoric of infants. The data is collected through a measurement for the gross and the fine motoric developments of the infants with an exclusive and a non-exclusive breast feeding, by using DDST and interview papers. The hypothesis test used is "t sample independent" statistic test. The results shown from the data of statistic test indicate that there is no difference in the development of the infants' fine motoric, whether they are given with an exclusive or a non-exclusive breast feeding, and neither does their gross motoric development. Breast feeding has no effect on both the gross and the fine motoric developments. The infants' motoric development evolves relying on their exercises.

Keywords : Infant, Exclusive and Non-Exclusive Breast Feeding, Gross and Fine Motorics 
Hermina Desitawati, Inge Wattimena, Natalia L Susanti : The Difference between ...

\section{PENDAHULUAN}

Masalah gizi yang paling utama di Indonesia pada saat ini adalah kurang kalori dan protein pada bayi. Hal tersebut menyebabkan terjadinya masalah pada perkembangan motorik pada bayi. Masalah perkembangan motorik pada bayi misalnya terjadinya keterlambatan perkembangan motorik dan kurang peka terhadap ransangan yang diberikan (Imam, 2011). Penyebab masalah perkembangan motorik pada bayi bukan hanya disebabkan oleh makanan yang diberikan tetapi juga karena Air Susu Ibu (ASI) banyak digantikan dengan susu kaleng atau susu formula dengan jumlah yang tidak memenuhi kebutuhan (Mariam, 2013). Pemberian ASI non eksklusif menyebakan terjadinya masalah pada status gizi bayi yaitu status gizi lebih dan status gizi buruk.

Peraturan Pemerintah Republik Indonesia dalam PP no.33 thn 2012 tentang Pemberian Air Susu Ibu Eksklusif mengharuskan setiap ibu yang melahirkan untuk memberikan ASI eksklusif kepada bayi yang dilahirkan sampai 6 bulan tanpa menambahkan dan / atau mengganti dengan makan atau minuman. Kenyataannya belum semua komponen masyarakat memahami kondisi ini, sehingga penggunaan ASI di Indonesia sebagai nutrisi utama pada bayi tidak menunjukkan angka statistik yang meningkat (Marlina, 2018). ASI belum sepenuhnya dimanfaatkan oleh masyarakat, bahkan terdapat kecendrungan terjadinya pergeseran susu formula pada sebagian kelompok masyarakat. Keluarga yang berpenghasilan rendah banyak yang beralih ke susu formula dalam bulan pertama kelahiran bayi untuk melengkapi makan atau akibat adanya hambatan menyusui (Rabaniya, 2011).

Penelitian yang dilakukan oleh di Poliklinik Neurologi Anak RS Dr. Ciptomangunkusumo Jakarta pada Januari-Juli 2008 tentang pravelensi Keterlambatan Perkembangan Global (KPG) didapatkan bahwa 151 (2,3\%) anak dari 6487 kunjungan mengalami KPG. Keluhan terbanyak, belum bisa berjalan dan berbicara $71(47,1 \%)$ kasus, $84(55,6 \%)$ laki-laki dan rata-rata umur $(21,8$ 13,1) bulan (Suwarba, 2012). Hasil studi (Mariam, 2013) dari 10 anak usia 1-3 tahun yang dinilai perkembangan motorik halusnya, 4 anak (40\%) normal dan 5 
anak (60) tidak normal. Terdapat dua faktor yang mempengaruhi terhadap tumbuh kembang anak adalah faktor genetik dan faktor lingkungan (Arya, 2011). Lingkungan disini merupakan bio-psiko-sosial dapat dikelompokkan dalam empat macam yaitu lingkungan keluarga, lingkunagn masyarakat, lingkungan pembinaan tumbuh kembang dan kesehatan anak dan lingkungan stimulus (Nurmiati \& Besral, 2011). Pemberian ASI sejak dini akan menstimulus perkembangan motorik dengan baik. Dalam hal ini, dukungan keluarga untuk memberikan ASI eksklusif kepada bayi sangat penting. Dengan memberikan ASI eksklusif bayi akan memiliki status gizi yang baik dan bisa melakukan pembinaan tumbuh kembang dengan baik (IDAI 2007).

\section{METODE}

Penelitian ini dilakukan untuk mengetahui perbedaan motorik halus dan kasar pada bayi yang diberikan ASI eksklusif dan ASI non-eksklusif. Penelitian ini dilakukan di Posyandu Puskesmas Pacarkeling Surabaya, Waktu penelitian dilakukan selama 14 hari. Penelitian ini bersifat observasional dengan desain compare. Variabel independen yaitu pemberian ASI sedangkan variabel dependen yaitu motorik kasar dan motorik halus. Populasi dalam penelitian semua bayi yang pernah mendapatkan ASI dengan usia 6-12 bulan. Sampel sebanyak 45 orang yang diambil dengan teknik purposive sampling dengan kriteria inklusi bayi yang tidak cacat fisik.

Penentuan responden, peneliti melakukan wawancara kepada ibu yang memiliki bayi usia 6-12 bulan yang pernah mendapatkan ASI. Wawancara dilakukan untuk mengetahui bayi yang diberikan ASI eksklusif dan ASI non eksklusif. Setelah pemilihan responden sesuai dengan kriteria inklusi, peneliti menjelaskan tentang tujuan penelitian yang akan dilakukan dan menjelaskan manfaat dari penelitian bagi responden. Selanjutnya responden yang bersedia menjadi subyek penelitian, menandatangani surat persetujuan berupa lembar informed consent. Responden akan dikaji perkembangan motorik halus dan motorik kasar menggunakan DDST yang sudah diperbaharui oleh Frankenburg dan J.B Dodds pada tahun 1990. Alat yang digunakan untuk mengkaji perkembangan motorik yaitu bola karet, kertas, pulpen dan gambar berwarna. Alat 
Hermina Desitawati, Inge Wattimena, Natalia L Susanti : The Difference between ...

tersebut sudah dinyatakan aman untuk digunakan untuk penelitian. Uji statistik yang digunakan untuk menilai perbedaan perkembangan motorik kasar maupun motorik halus bayi yang mendapatkan ASI eksklusif dan ASI non eksklusif adalah uji $t$ sample independent.

\section{HASIL}

Penelitian ini dilakukan di Posyandu Puskesmas Pacarkeling Surabaya, Waktu penelitian dilakukan selama 14 hari.

Tabel 1. Data Umum Bayi Usia 6-12 bulan Posyandu Puskesmas Pacarkeling Surabaya

\begin{tabular}{cccc}
\hline Data Responden & $\begin{array}{c}\text { Kategori } \\
\text { (bulan) }\end{array}$ & $\begin{array}{c}\text { N (jumlah } \\
\text { responden) }\end{array}$ & Presentase (\%) \\
\hline Usia & 6 & 8 & $18 \%$ \\
& 7 & 12 & $27 \%$ \\
& 8 & 4 & $9 \%$ \\
& 9 & 3 & $6 \%$ \\
& 10 & 5 & $11 \%$ \\
Jeniskelamin & 11 & 4 & $9 \%$ \\
& 12 & 9 & $20 \%$ \\
Pemberian ASI & Laki -laki & 26 & $58 \%$ \\
& Perempuan & 19 & $42 \%$ \\
& ASI eksklusif & 18 & $40 \%$ \\
& ASI non eksklusif & 27 & $60 \%$ \\
\hline
\end{tabular}

Tabel 1, menunjukkan bahwa responden terbanyak adalah bayi usia 7 bulan, jenis kelamin laki-laki dan ASI non eksklusif.

Tabel 2 Distribusi Responden yang Mendapatkan ASI Eksklusif Berdasarkan Perkembangan Motorik Halus dan Motorik Kasar Di Posyandu Puskesmas Pacar keling

\begin{tabular}{lcccc}
\hline Kategori & \multicolumn{2}{c}{ Motorik Halus } & \multicolumn{2}{c}{ Motorik Kasar } \\
& $\Sigma$ & $\%$ & $\sum$ & $\%$ \\
\hline Normal & 14 & 78 & 12 & 67 \\
Tidak normal & 4 & 22 & 6 & 33 \\
Jumlah & 18 & $100 \%$ & 18 & $100 \%$ \\
\hline
\end{tabular}


Tabel 2, Menunjukkan bahwa responden yang diberikan ASI eksklusif memiliki perkembangan motorik kasar dan halus yang normal.

Tabel 3 Distribusi Responden yang Mendapatkan ASI Non Eksklusif Berdasarkan Perkembangan Motorik Halus dan Motorik Kasar DI Posyandu Puskesmas Pacar keling

\begin{tabular}{lcccc}
\hline Kategori & \multicolumn{2}{c}{ Motorik Halus } & \multicolumn{2}{c}{ Motorik Kasar } \\
& $\sum$ & \% & $\sum$ & \% \\
\hline Normal & 20 & 74 & 15 & 56 \\
Tidak normal & 7 & 26 & 12 & 44 \\
Jumlah & 27 & $100 \%$ & 27 & $100 \%$ \\
\hline
\end{tabular}

Tabel 3, menunjukkan bahwa responden yang diberikan ASI non eksklusif sebagian besar memiliki perkembangan motorik kasar dan halus yang normal.

Table 4 Tabulasi Silang ASI Esklusif Dan ASI Non Eksklusif Dengan Motorik Halus Pada Bayi Di Posyandu Puskesmas Pacarkeling Surabaya.

\begin{tabular}{lcccc}
\hline \multirow{2}{*}{ Kategori } & \multicolumn{2}{c}{ Bayi 6-9 bulan } & \multicolumn{2}{c}{ Bayi 10-12 bulan } \\
& Normal $(\%)$ & $\begin{array}{c}\text { Tidak normal } \\
(\%)\end{array}$ & $\begin{array}{c}\text { Normal } \\
(\%)\end{array}$ & $\begin{array}{c}\text { Tidak normal } \\
(\%)\end{array}$ \\
\hline ASI eksklusif & 12 & 88 & 77 & 23 \\
ASI non & 5 & 95 & 77 & 23 \\
Ekslusif & & & & \\
\hline
\end{tabular}

Tabel 4, menunjukkan bahwa bayi 10-12 bulan adalah responden memiliki perkembangan motorik kasar dan halus yang sebagian besar normal. Dalam penelitian ini, peneliti menggunakan uji statistik $t$ sample independent di program spsss versi 21 dengan tingkat signifikan $($ Alpha $)=0,05$. Berdasarkan hasil uji statistik bayi usia 6-9 bulan mendapatkan hasil bahwa nilai P: 0,740 yang berarti nilai $\mathrm{P}>\alpha$ 0,05, sehingga dapat disimpulkan tidak adanya perbedaan perkembangan motorik halus pada bayi yang mendapatkan ASI eksklusif dan ASI non eksklusif. Dari hasil uji statistik bayi usia 10-12 bulan mendapatkan hasil bahwa nilai $\mathrm{P}: 0,691$ yang berarti nilai $\mathrm{P}>\alpha 0,05$, sehingga dapat disimpulkan tidak adanya perbedaan perkembangan motorik halus pada bayi yang mendapatkan ASI eksklusif dan ASI non eksklusif. Berdasarkan hasil uji statistik mendaptkan hasil bahwa nilai $\mathrm{P}$ : 1,046 yang berarti nilai $\mathrm{P}>\alpha 0,05$, sehingga bisa disimpulkan bahwa tidak adanya perbedaan perkembangan motorik kasar pada bayi yang mendapatkan ASI eksklusif dan ASI non eksklusif. 
Hermina Desitawati, Inge Wattimena, Natalia L Susanti : The Difference between ...

\section{PEMBAHASAN}

Hasil pengkajian terhadap 45 bayi yang mendapatkan ASI eksklusif adalah 18 bayi menunjukan bahwa terdapat 14 bayi (78\%) yang motorik halus normal, 4 bayi (22\%) yang motorik halus tidak normal sedangkan terdapat 12 bayi (67\%) yang motorik kasar normal, 6 bayi (33\%) yang motorik kasar tidak normal. Menurut (Proverawati, A. \& Rahmawati, 2012) bayi yang mendapatkan ASI eksklusif selama 6 bulan tanpa ada makanan tambahan akan merangasang perkembangan bayi secara normal karena lebih banyak mendapatkan zat-zat gizi yang sesuai dengan kebutuhan bayi, dan sebagai stimulus untuk perkembangan motorik dimana adanya komunikasi antara ibu dan bayi serta ikatan batin.

Hasil penelitian yang dilakukan oleh (Anisah, 2016) bahwa bayi yang mendapatkan ASI eksklusif mengalami tumbuh kembang yang normal. Hasil penelitian ini sama dengan yang dilakukan oleh (Aisyah, 2017) bahwa bayi yang mendapatkan ASI eksklusif mengalami tumbuh kembang yang lebih cepat. Bayi yang mendapatkan ASI ekslusif memiliki status gizi yang baik sehingga bayi mampu melakukan kemampuan motorik kasar maupun motorik halus dengan baik.

Peneliti berpendapat bahwa, terdapat beberapa faktor yang mempengaruhi perkembangn motorik halus dan motorik kasar. Faktor utama adalah gizi, dimana bayi yang mendapat ASI eksklusif akan memiliki perkembangan yang lebih baik. Bayi yang mendapatkan ASI eklusif akan mendapatkan status gizi yang baik sehingga dalam melakukan aktivitas perkembangan motorik bayi dapat melakukan dengan baik. Hal ini sesuai dengan data yang didapatkan pada saat penelitian yaitu dari 18 bayi bayi yang mendapatkan ASI eksklusif ada 14 bayi (78\%) yang motorik halus normal dan ada 12 bayi (67\%) yang motorik kasar normal.

Hasil penelitian mendapatkan ada 27 bayi yang mendapatkan ASI non eksklusif menunjukkan bahwa sebanyak 20 bayi (74\%) motorik halus normal, 7 bayi (26\%) motorik halus tidak normal dan 15 bayi (56\%) motorik kasar normal, 12 bayi (44\%) motorik kasar tidak normal. Menurut (Proverawati, A. \& Rahmawati, 2012) bayi yang ASI non eksklusif adalah bayi yang mendapatkan 
ASI tetapi ditambahkan dengan makanan pendamping ASI seperti air, susu formula, pisang,bubur dll. Makanan pendamping ASI tersebut yang banyak berpengaruh untuk tubuh bayi, sehingga tumbuh kembang yang didapatkan bayi juga akan berpengaruh.

Hasil penelitian (Aliya, 2014) mengatakan bahwa bayi yang mendapatkan ASI non eksklusif memiliki pertumbuhan berat badan yang tidak normal yaitu berat badan lebih dan berat badan kurang dikarenakan adanya pengaruh dari faktor makanan pendamping ASI, sehingga menyebabkan perkembangan motorik terganggu karena bayi yang memiliki berat badan lebih dan berat badan kurang susah untuk melalukan aktivitas bergerak. Peneliti berpendapat bahwa bayi yang memiliki perkembangan motorik normal sering melakukan latihan dan olahraga.

Hal tersebut sesuai dengan hasil wawancara yang dilakukan kepada ibu yang memiliki bayi ASI non eksklusif yang mengatakan bahwa bayinya sering diberikan latihan dan diberikan ransangan misalnya latih merangkak, latih untuk berdiri dan latih untuk membalikkan badan dengan bantuan ibu atau pengasuh. Dari hasil penelitian ini terdapat 7 bayi (26\%) yang mengalami motorik halus tidak normal, dan 12 bayi (44\%) yang mengalami motorik kasar tidak normal yang merupakan sebagian besar dari bayi tersebut mengalami berat badan lebih dan berat badan kurang. Hasil pengukuran 8 bayi (42\%) mengalami berat badan lebih yaitu 9,34 kg-11,2 kg, dan 4 bayi (21\%) mengalami berat badan kurang yaitu 6,34 kg- 7,60 kg. Bayi yang mengalami perkembangan motorik tidak normal disebabkan karena jarang melakukan latihan perkembangan motorik. Hal tersebut sesuai dengan hasil wawancara yang dilakukan pada ibu bahwa bayi jarang dilatih karena tidak ada waktu untuk melakukan latihan karena sibuk bekerja.

Hasil penelitian dari (Aliya, 2014), tentang pengaruh status gizi terhadap perkembangan motorik mendapatkan hasil bahwa bayi yang memiliki status gizi baik, sebagian besar mengalami perkembangan motorik halus normal dan bayi yang memiliki status gizi yang cukup sebagian besar mengalami perkembangan motorik halus normal. Kesimpulan bahwa perkembangan motorik halus tidak dapat diukur dari status gizi yang dialami bayi tetapi dilihat dari seberapa sering bayi dilatih dan dirangsang sistem syarafnya. Hasil penelitian ini juga memiliki 
Hermina Desitawati, Inge Wattimena, Natalia L Susanti : The Difference between ...

hasil yang sama dimana tidak ada perbedaan secara signifikan antara perkembangan motorik halus pada bayi yang mendapatkan ASI eksklusif dan ASI non eksklusif.

Hasil wawancara yang dilakukan pada setiap ibu tentang cara untuk meransang perkembangan motorik halus, banyak ibu yang menggunakan cara dengan berkomunikasi dengan bayi. Harapan ibu, dengan berkomunikasi ransangan motorik halus bayinya bisa berfungsi dengan baik. Pemberian ASI ekelusif dan ASI non eksklusif kepada bayi tidak memberikan dampak yang besar bagi perkembangan motorik halus bayi, karena hasil penelitian menunjukkan tidak adanya perbedaan signifikan. Oleh karena itu, diharapkan kepada petugas kesehatan untuk memberikan penyuluhan dan mengajarkan kepada ibu yang memiliki bayi tentang deteksi dini perkembangan motorik halus.

Hasil penelitian dari (Aliya, 2014), tentang pengaruh status gizi terhadap perkembangan motorik mendapatkan hasil bahwa bayi dengan status gizi lebih $65 \%$ bayi memilki perkembangan motorik kasar normal. Sedangkan pada bayi yang status gizi kurang $55 \%$ bayi memiliki pekembangan motorik kasar normal. Hal ini disebabkan karena ibu dari bayi sering memberikan latihan pada bayinya dan mengikuti olahraga yang bisa meransang perkembangan motorik kasar. Pada bayi yang memiliki status gizi baik $67 \%$ memiliki perkembangan motorik kasar normal.

Penelitian (Aliya, 2014), mengatakan bahwa pengaruh terbesar kenaikan berat badan dan penurunan berat badan pada bayi adalah pemberian makanan pengganti atau penambah ASI pada bayi yang tidak ASI eksklusif. Hasil penelitiannya mengatakan sebanyak $67 \%$ bayi mengalami berat badan lebih dan berat badan kurang. Dalam penelitiannya mengatakan perkembangan motorik kasar tidak berpengaruh dari pemberian ASI eksklusif dan ASI non eksklusif, karena perkembangan motorik kasar sangat bergantung pada seberapa sering bayi dilatih untuk digerakkan tubuhnya sehingga bayi terbiasa. Pada kesimpulan juga dijelaskan bahwa perkembangan motorik kasar tidak ada kaitannya dengan ASI, karena ASI hanya berpengaruh ke status gizi bayi bukan perkembangan motorik kasar. Perkembangan motorik kasar dipengaruhi ransangan dari luar seperti latian 
fisik. Frekuensi latian fisik yang sering akan mempengaruhi otot-otot bayi sehingga bayi tidak kaku dan motorik kasar berkembang dengan baik. Latian fisik dilakukan sesuai dengan usia bayi untuk menjaga keseimbangan perkembangan motorik (Proverawati, A. \& Rahmawati, 2012) . Pemberian ASI eksklusif dan ASI non eksklusif tidak berpengaruh terhadap perkembangan motorik kasar bayi, karena hasil penelitian menunjukkan tidak ada perbedaan secara signifikan. Oleh karena itu, diharapkan semua ibu diajarkan cara untuk memberikan latihan yang bisa merangsang perkembangan motorik kasar sehingga nantinya melakukan deteksi dini perkembangan motorik kasar pada bayi.

\section{SIMPULAN}

Berdasarkan hasil penelitian yang dilakukan mendapatkan hasil bahwa bayi yang mendapatkan ASI eksklusif memiliki perkembangan motorik halus dan motorik kasar yang sebagian besar normal dan bayi yang mendapatkan ASI non eksklusif memiliki perkembangan motorik halus yang sebagian besar normal sedangakan perkembangan motorik kasar yang sebagian normal. Hasil penelitian ini menunjukkan bahwa tidak ada perbedaan yang signifikan perkembangan motorik halus pada bayi yang diberikan ASI eksklusif dan ASI non eksklusif dan tidak ada perbedaan yang signifikan perkembangan motorik kasar pada bayi yang diberikan ASI eksklusif dan ASI non eksklusif.

\section{UCAPAN TERIMAKASIH}

Terima kasih kepada pendamping dan pembimbing Fakultas Keperawatan, Universitas Katolik Widya Mandala Surabaya sehingga penelitian ini bisa di selesaikan dengan tepat waktu. Ucapan terima kasih juga penulis sampaikan kepada semua pihak yang telah membantu tulisan ini selesai hingga dipublikasi.

\section{DAFTAR PUSTAKA}

Aisyah, S. (2017) Pengaruh ASI Eksklusif Terhadap Tumbuh Kembang Usia 0-12 Bulan. Fakultas Kedokteran Universitas Sumatera Utara. 10.1016/j.jaci.2005.03.036

Aliya (2014) 'Pengaruh Status Gizi Terhadap Perkembangan Motorik Pada Bayi Usia 0-12 Bulan', Fakultas Keperawatan Universitas Sumatera Utara, 1(2). 10.1017/jns.2016.41

Anisah (2016) 'Pengaruh ASI eksklusif terhadap Tumbuh Kembang Bayi usia 0-6 bulan'. Elsevier. 10.1161/JAHA.112.000497

Arya (2011) 'Pengaruh terapi aktivitas motorik terhadap perkembangan motorik 
Hermina Desitawati, Inge Wattimena, Natalia L Susanti : The Difference between ...

pada anak usia 0-12 bulan', (August), pp. 5-10. doi: 10.15744/24557641.4.104.

Dinkes Jawa Timur. (2015). Profil Kesehatan Jawa Timur 2015. http//:3578_Jatim_Kota_Surabaya_2015.

IDAI. (2007). Pedoman Pelaksanaan Stimulus Deteksi Dini dan Intervensi Tumbuh Kembang Anak. Jakarta. DEPKES RI

E, Marlina. (2018) 'Hubungan Pengetahuan Sikap Dan Perilaku Tentang Stimulus Dini Dengan Perkembangan Motorik Halus Pada Anak Usia 1-3 Tahun Di Desa Gempolan Kecamatan Gurah Kabupaten Kediri.', Journal of Dairy Science. Fakultas Kedokteran Sebelas Maret Surakarta, pp. 1-4. doi: 10.3168/jds.2017-13868.

Imam, M. (2011) 'Pengaruh ASI eksklusif dan ASI non eksklusif terhadap status gizi dan tumbuh kembang bayi usia 0-12 bulan.', Fakultas Ilmu Keperawatan universitas Klabat, 16, pp. s27-s42. doi: 10.5604/01.3001.0010.5495.

Mariam (2013) 'Faktor-Faktor Yang Mempengaruhi Tumbuh Kembang Bayi Usia 0-12 Bulan', Fakultas Keperawatan Universitas Negeri Makasar. 10.1016/j.jaci.2005.03.036

Nurmiati \& Besral (2011) 'Durasi Pemberian ASI Terhadap Ketahanan Hidup Bayi Indonesia', 12(2). doi: 10.5402/2011/892971.

Nursalam (2011). Konsep dan Penerapan Metodologi Penelitian Ilmu Keperawatan: Pedoman Skripsi, Tesis dan Instrumen Penelitian Keperawatan. Jakarta: Salemba Medika.

Peraturan Pemerintah RI (2012) “Peraturan Pemerintah Republik Indonesia Nomor 33 Tahun 2012 tentang Pemberian Air Susu Ibu Eksklusif” Jakarta. DEPKES RI

Proverawati, A. \& Rahmawati, E. (2012) ASI dan Menyusui. Yogyakarta.

Rabaniya, S. \& (2011) Gambaran Perilaku dan Faktor-faktor yang berhubungan dengan Pemberian ASI Eksklusif. 10.2337/db07-1403.Additional

Riwikdido. (2017). Hubungan Pola Asuh Orangtua Dengan Perkembangan Motorik Pada Anak Usia Pra Sekolah. Program Master Psikologi Universitas Kristen Maranatha. 10.1186/s12544-016-0358-4

Soetjiningsih, \& I.G.N.Gde Ranuh. (2013). Tumbuh Kembang Anak. Ed 2. Jakarta: EGC.

Suwarba, I. G. N. (2012) 'Profil Klinik dan Etiologi Pasien Keterlambatan Perkembangan Global di Rumah Sakit Cipto Mangunkusumo Jakarta', 10(4). 10.1186/s12944-016-0278-4

\begin{tabular}{|l|l|}
\hline Submission & 14 Januari 2020 \\
\hline Review & 15 Januari 2020 \\
\hline Accept & 29 Maret 2020 \\
\hline Publish & 23 April 2020 \\
\hline DOI & $10.29241 /$ jmk.v\%vi\%i.294 \\
\hline Sinta Level & 4 (Empat) \\
\hline
\end{tabular}

